\title{
EFEKTIVITAS ANTIBAKTERI EKSTRAK HERBA MENIRAN (Phylanthus niruni) TERHADAP PERTUMBUHAN BAKTERI Salmonella sp. dan Propionibacterium acnes
}

\author{
I.Fitri ${ }^{1}$, D.I. Widiyawati ${ }^{2}$ \\ 1 Jurusan Biologi, Fakultas Sains \\ 2 Jurusan Analis Kesehatan, Fakultas IImu Kesehatan \\ Institut IImu Kesehatan Bhakti Wiyata \\ Kediri, Indonesia
}

e-mail: f.inayah89@gmail.com,devisika87@gmail.com

\begin{abstract}
Abstrak
Meniran (Phyllanthus niruni L.) merupakan jenis herba yang tumbuh liar di tempat lembab dan berbatu, seperti semak - semak dan tanah di antara rerumputan, akan tetapi memiliki khasiat sebagai obat. Meniran juga berpotensi sebagai antibakteri karena banyak mengandung komponen bioaktif seperti alkaloid, flavonoid, tanin, dan saponin. Bakteri Gram negatif seperti Salmonella sp. dan bakteri Gram positif seperti Propionibacterium acnes merupakan bakteri yang digunakan dalam penelitian ini. Penelitian ini bertujun untuk mengetahui efektivitas antibakteri ekstrak herba meniran terhadap bakteri Salmonella sp. dan $P$. acnes dengan mengamati zona hambat yang terbentuk. Jenis penelitian ini yaitu eksperimental dengan metode disk diffusion. Sampel herba meniran diambil dari Kecamatan Bandar Lor Kediri, kemudian diekstraksi dengan metode maserasi menggunakan pelarut etanol $96 \%$. Hasil penelitian menunjukkan rata - rata diameter zona hamba dari ekstrak herba meniran terhadap Salmonella sebesar $20 \mathrm{~mm}$ dan terhadap $P$. acnes sebesar 19,6 mm. Kesimpulan dari penelitian ini ialah ekstrak herba meniran memiliki efektifitas sebagai antibakteri dalam mengahambat pertumbuhan bakteri Salmonella dan P. acnes.
\end{abstract}

Kata kunci: efektivitas, antibakteri, herba meniran, Salmonella, P. acnes.

\begin{abstract}
Phyllanthus niruni is a type of herb that grows wild in moist and rocky places, such as bushes and soil among the grass, but later know as traditional medicine. $P$. niruni is also potential as an antibacterial because it contains many bioactive components such as alkaloids, flavonoids, tannins, and saponins. Negative Gram bacteria such as Salmonella sp. and positive Gram bacteria such as $P$. acnes, there were two species of bacteria used in this study. The study aimed to determine antibacterial effectivity of $P$. niruni extract to againt Salmonella dan $P$. acnes by measuring the diameters of the inhibition zones. This type of research is experimental with disk diffusion method. $P$. niruni samples were taken from Bandar Lor Kediri, and then be extracted by maceration using $96 \%$ etanol. The result showed that the average diameter of the inhibition zone of $P$. niruni extract to againt Salmonella of $20 \mathrm{~mm}$ and to againt $P$. acnes of $19,6 \mathrm{~mm}$. The conclusion this research is $P$. niruni extract had antibacterial effectivity to againt Salmonella dan P. acnes.
\end{abstract}

Keyword: effectiveness, antibacterial, P. niruni herbs, Salmonella, P. acnes

\section{PENDAHULUAN}

Indonesia merupakan mega biodiversity country yaitu negara yang mempunyai keanekaragaman hayati tinggi. Hal ini dapat dibuktikan bahwa sekitar 9.600 spesies flora di Indonesia diketahui berkhasiat sebagai obat (Kardinan dan Fauzi, 2004). Keanekaragaman hayati yang saat ini menjadi perhatian para peneliti adalah keanekaragaman tanaman obat. Salah 
satu dari beberapa tanaman obat yang banyak diteliti akhir - akhir ini ialah tumbuhan dari genus Phyllanthus. Genus Phyllanthus merupakan kelompok genus yang memiliki spesies yang cukup banyak yaitu mencapai 833 spesies. Beberapa contoh spesies yang termasuk genus Phyllanthus seperti Phyllanthus niruni (meniran hijau), Phyllanthusurinaria (meniran merah), Phyllanthusacidus (ceremai), Phyllanthus buxifolius (sligi), Phyllanthus reticulates (buah tinta) (Hariyani dkk, 2013).

Meniran (Phyllanthus niruni L.) merupakan jenis herba dari famili Euphorbiaceae yang tumbuh liar di tempat lembab dan berbatu, seperti semak semak dan tanah di antara rerumputan (Djauhari dan Hermani, 2004). Ciri dari herba meniran yaitu tumbuh tegak dengan tinggi $30-60 \mathrm{~cm}$, batang hijau; daun bentuk bulat telur hingga memanjang, ujung daun tumpul, pangkal membulat, permukaan bawah berbintik dan tepi daun rata; buah terletak di bawah daun dan letak tertata sepanjang tangkai utama daun (Paithankar et al., 2011).

Pada Surat keputusan Menteri Kesehatan Republik Indonesia melalui Peraturan Menteri Kesehatan No 003 / MENKES / PER / I / 2010 pada Pasal I menjelaskan bahwa saintifikasi jamu ialah pembuktian ilmiah jamu melalui penelitian yang berdasarkan pelayanan kesehatan, sedangkan jamu merupakan ramuan yang berasal dari tumbuhan atau dari resep turun menurun yang digunakan untuk pengobatan dan diterapkan sesuai dengan aturan yang ada.

Pada saat ini penggunaan antibiotik maupun antibakteri banyak mengandung bahan kimiawi tertentu yang dapat mengiritasi pankreas sehingga menyebabkan radang pankreas. Peradangan pada pankreas dapat mengakibatkan pankreas tidak berfungsi secara optimal dalam mensekresikan hormon yang diperlukan untuk metabolisme dalam tubuh, termasuk hormone insulin (Hadiki, 2014).

Herba meniran juga berpotensi sebagai antibakteri. Hal ini didukung penelitian dari Rahman dkk (2012), menyimpulkan bahwa adanya perbedaan efek antibakteri ekstrak etil asetat dan kloroform herba meniran yang diujikan pada bakteri Escherichia coli dan Staphylococcus aureus. Ekstrak etil asetat meniran berpengaruh hanya pada pertumbuhan bakteri Staphylococcus aureus sedangkan ekstrak kloroform meniran berpengaruh pada bakteri Staphylococcus aureus dan Escherichia coli. Bagian dari herba meniran (daun, akar dan batang) memiliki banyak manfaat sebagai obat tradisional, karena mengandung beberapa senyawa kimia yaitu alkaloid (sekurinin), flavonoid (kuersetin, kuersitrin, isokuersitrin, astragalin, nirunin, niruside, rutin, leukodelfinidin dan galakotekin), dan lignan (filantin dan hipofilantin) (Muharram dan Nur, 2009; Paithankar et al., 2011; Hariyani dkk, 2013; Rivai dkk, 2013). Daun meniran ( $P$. niruri) merupakan tumbuhan yang memiliki aktivitas antibakteri paling banyak dibandingkan bagian-bagian yang lain seperti batang dan akar karena banyak mengandung komponen bioaktif seperti alkaloid, flavonoid, tanin, dan saponin (Bukar, 2010).

Salmonella sp. merupakan beberapa contoh dari bakteri Gram negatif. Salmonella sp. merupakan penyebab utama keracunan pada makanan yang dapat menyebabkan gastroenteritis dan juga merupakan bakteri penyebab terjadinya demam tipoid (Pui et al., 2011; Mahmoud, 2012). Propionibacterium acnes merupakan contoh dari bakteri Gram positif yang 
dapat menyebabkan infeksi jerawat. $S$. aureus merupakan bakteri yang dapat menyebabkan penyakit meningitis, pneumonia, endokarditis dan infeksi kulit. Bakteri ini juga dapat menyebabkan penyakit kulit seperti bisul dan eksim (Fatisa, 2013).

Berdasarkan latar belakang di atas, adapun tujuan dari penelitian ini yaitu untuk mengetahui pengaruh ekstrak etanol meniran terhadap berbagai bakteri yaitu Salmonella sp. dan Propionibacterium acnes.

\section{METODE PENELITIAN}

Penelitian ini terdiri dari beberapa tahap, yaitu pembuatan ekstrak daun meniran yang dilakukan di Laboratorium Biologi Farmasi, pembuatan media untuk peremajaan bakteri dan uji antibakteri dilakukan di Laboratorium Media, peremajaan dan pengujian ekstrak terhadap bakteri dilakukan di Laboratorium Bakteriologi Institut IImu Kesehatan Bhakti Wiyata Kediri pada bulan Juni - Juli 2017.

Jenis penelitian ini yaitu eksperimental laboratorium. Variabel bebas (independent) dalam penelitian ini ialah ekstrak metanol herba meniran. Variabel terikat (dependent) dalam penelitian ini ialah baktei uji Salmonella sp dan Propionibacterium acnes. Variabel kontrol dalam penelitian ini ialah herba meniran, kelarutan ekstrak, media Muller Hinton Agar (MHA), waktu inkubasi, suhu, metabolisme kuman, dan umur tumbuhan.

Sampel yang digunakan adalah herba meniran yang didapatkan di Kecamatan Bandar Lor Kediri. Pembuatan ekstrak dilakukan secara maserasi yaitu salah satu metode ekstraksi padat - cair bertahap yang dilakukan dengan jalan membiarkan padatan terendam dalam suatu pelarut (Kristanti dkk, 2008) dan uji antibakteri menggunakan metode disk diffusion yaitu metode yang sering digunakan karena mudah dilakukan, praktis dan cukup teliti (Pratiwi, 2008). Hasil didapatkan dengan menghitung zona jernih yang terbentuk akibat aktivitas ekstrak herba meniran terhadap bakteri uji.

Untuk mengetahui ada tidaknya perbedaan tiap perlakuan dengan konsentrasi ekstrak yang berbeda terhadap bakteri Salmonella sp. dan $P$. acnes, data zona jernih dianalisis menggunakan uji One Way Anova dengan taraf kesalahan 5\%, jika terdapat perbedaan maka dilanjutkan dengan uji Tukey.

\section{Alat dan Bahan}

Alat

Alat yang digunakan dalam penelitian ini meliputi plate, beaker glass, tabung reaksi, erlenmayer, gelas ukur, spatel, timbangan digital, pipet steril, inkase, autoclave, rotary evaporator, oven, inkubator, kulkas, rak tabung, ose, swab steril, jangka sorong, kamera sebagai alat dokumentasi.

\section{Bahan}

Bahan - bahan yang digunakan dalam penelitian ini ialah media Mueller Hinton Agar (MHA), Selenith Broth (SB), $\mathrm{NaCl}$ Broth, Salmonella Shigella Agar (SSA), Mannitol Salt Agar (MSA), aquadest, daun meniran, metanol, kertas label, spirtus, aluminum foil, kultur bakteri, spirtus, alkohol $70 \%$.

\section{Prosedur Penelitian}

a. Pembuatan ekstrak metanol herba meniran (Kristanti dkk, 2008)

Mengumpulkan daun herba
meniran sebanyak 300 gram,
kemudian dikeringanginkan pada
suhu ruangan. pembuatan ekstrak

Jurnal Sains dan Teknologi | 302 
dilakukan secara maserasi, yaitu merendam potongan daun yang kering ke dalam erlenmayer yang berisi etanol kemudian dikocok hingga homogen \pm selama 1 jam lalu dibiarkan selama 24 jam. Perendalam diulang sebanyak 3 kali. Filtrat hasil ekstraksi dikumpulkan menjadi satu, kemudian dievaporasi menggunakan rotary evaporator.

\begin{tabular}{lr}
\multicolumn{2}{c}{ Pembuatan konsentrasi } \\
ekstrak dilakukan & dengan \\
menambahkan aquades & sebagai
\end{tabular}
pelarutnya. Pada pembuatan ekstrak konsentrasi $10 \%$ menambahkan 0,2 $\mathrm{ml}$ ekstrak dan 1,8 $\mathrm{ml}$ aquades; pada konsentrasi $30 \%$ menambahkan 0,6 $\mathrm{ml}$ ekstrak dan 1,4 $\mathrm{ml}$ aquades; pada konsentrasi 50\% menambahkan 1,0 $\mathrm{ml}$ ekstrak dan 1,0 ml aquadest; pada konsentrasi $70 \%$ menambahkan 1,4 $\mathrm{ml}$ ekstrak dan 0,6 $\mathrm{ml}$ aquades; dan pada konsentrasi $90 \%$ menambahkan $1,8 \mathrm{ml}$ ekstrak dan $0,2 \mathrm{ml}$ aquades.

b. Pembuatan media untuk peremajaan dan uji antibakteri

Membuat media MHA untuk uji antibakteri; SB untuk media pemupuk dan SSA media selektif dari Salmonella sp; $\mathrm{NaCl}$ Broth untuk media pemupuk dan MSA media selektif $P$. acnes. Pembuatan media dilakukan dengan steril autoclave. Alat - alat yang digunakan, sebelumnya juga disterilkan oven. Menuang media yang sudah disteril autoclave pada plate yang steril.

\section{HASIL DAN PEMBAHASAN}

Pada penelitian ini dilakukan pengamatan dengan 4 kali pengulangan dari antibakteri ekstrak herba meniran terhadap bakteri Salmonella dan $P$. acnes, diketahui pada tiap konsentrasi menunjukkan terbentuknya zona hambat yang ditandai dengan adanya daerah c. Peremajaan bakteri uji

$$
\text { Meremajakan }
$$

bakteri

Salmonella sp dan $P$. acnes yang ada di Laboratorium Bakteriologi, dengan menyetrikkan bakteri Salmonella sp dan $P$. acnes yang pada media selektif kemudian diinkubasi selama 24 jam dengan suhu $34^{\circ} \mathrm{C}$. Menyocokkan ciri bakteri yang tumbuh ada media selektif dengan buku Bergey's. Jika sudah sesuai, maka dilakukan penanaman di media pemupuk kemudian diinkubasi selama 24 jam dengan suhu $34^{\circ} \mathrm{C}$.

d. Uji antibakteri (Pratiwi, 2008)

Menyetrikkan bakteri Klebsiella sp, E. coli, Salmonella sp, $S$. aureus dan $P$. acnes pada plate yang berisi media MHA. Disk blank dengan diameter $6 \mathrm{~mm}$ dibasahi dengan ekstrak metanol herba meniran, kemudian diletakkan pada media yang sudah memadat dan diberi bakteri sebelumnya. Plate tersebut diinkubasi dalam inkubator selama 24 jam dengan suhu $34^{\circ} \mathrm{C}$. Jika ekstrak etanol herba meniran dapat menghambat pertumbuhan bakteri, maka akan terlihat adanya daerah jernih di sekeliling disk blank. Luas zona jernih berkaitan dengan kecepatan berdifusinya ekstrak etanol herba meniran dalam media MHA dan juga merupakan petunjuk kepekaan bakteri terhadap ekstrak, dan menjadi ukuran kekuatan daya kerja dengan aktivitas antibakteri.

bening di sekitar cakram disk. Pada Tabel 1, ekstrak daun herba konsentrasi $10 \%$ dan $30 \%$ yang diujikan terhadap bakteri Salmonella sp. bersifat resisten, konsentrasi $50 \%$, 70\% dan $90 \%$ bersifat sensitif; sedangkan pada ekstrak daun herba konsentrasi $10 \%$ dan $30 \%$ yang diujikan terhadap bakteri $P$.acnes bersifat 
resisten, konsentrasi $50 \%$ bersifat intermediet, dan konsentrasi $70 \%$ serta $90 \%$ bersifat sensitif jika dibandingkan dengan kontrol (+). Daya hambat ditandai dengan adanya daerah jernih di sekitar cakram disk. Sensitif adalah kemampuan ekstrak dalam menghambat dan membunuh bakteri. Intermediet adalah kemampuan suatu ekstrak yang dapat menghambat tetapi tidak mampu membunuh bakteri. Resisten adalah suatu sifat tidak terganggunya kehidupan sel mikroorganisme oleh antibiotik.

Uji Normalitas bertujuan untuk mengetahui suatu data penelitian berdistribusi normal atau tidak. Pada Tabel 2, untuk uji normalitas menggunakan uji statistik Shapiro Wilk karena jumlah sampel $<50$. Hasil uji ekstrak herba meniran terhadap bakteri $P$. acne pada konsentrasi 10\%, 30\%, 50\%, $70 \%$, dan $90 \%$ merupakan data yang terdistribusi secara normal, karena nilai signifikansi dari masing - masing konsentrasi > 0,05.

Hasil uji ekstrak herba meniran terhadap bakteri Salmonella pada konsentrasi $10 \%, 30 \%, 50 \%, 70 \%$, dan $90 \%$ juga merupakan data yang terdistribusi secara normal, karena nilai signifikansi dari masing - masing konsentrasi $>0,05$. Dari perhitungan uji normaliltas tersebut dapat dihitung rata rata zona hambat dan standart deviasi pada tiap konsentrasi terhadap bakteri $P$. acne dan Salmonella. Jika dilihat dari tiap konsentrasi, maka terdapat kenaikan zona hambat dari konsentrasi 10\% hingga $90 \%$ terhadap kedua bakteri yaitu $P$. acne dan Salmonella (Tabel 2).

Tabel 1. Rata - Rata Daya Hambat yang Terbentuk Akibat Tiap - tiap Konsentrasi Terhadap Bakteri P.acne dan Salmonella

\begin{tabular}{|c|c|c|c|c|c|}
\hline \multirow{2}{*}{ Konsentrasi } & \multirow{2}{*}{ Replikasi } & \multicolumn{2}{|c|}{ Salmonella } & \multicolumn{2}{|c|}{ P.acnes } \\
\hline & & Daya hambat (mm) & Rata-rata $(\mathrm{mm})$ & Daya hambat (mm) & Rata-rata $(\mathrm{mm})$ \\
\hline $10 \%$ & $\begin{array}{l}1 \\
2 \\
3 \\
4\end{array}$ & $\begin{array}{l}6,3 \\
6,7 \\
6,1 \\
6,4\end{array}$ & 6,3 & $\begin{array}{l}7,0 \\
7,9 \\
7,6 \\
7,7\end{array}$ & 7,5 \\
\hline $30 \%$ & $\begin{array}{l}1 \\
2 \\
3 \\
4 \\
1\end{array}$ & $\begin{array}{l}10,9 \\
11,9 \\
11,3 \\
12,3 \\
12,9\end{array}$ & 11,6 & $\begin{array}{c}9,3 \\
10,8 \\
12,3 \\
12,0 \\
12,1\end{array}$ & 11,1 \\
\hline $50 \%$ & $\begin{array}{l}2 \\
3 \\
4\end{array}$ & $\begin{array}{l}13,6 \\
14,8 \\
15,0\end{array}$ & 14,1 & $\begin{array}{l}14,8 \\
13,2 \\
15,0\end{array}$ & 13,7 \\
\hline $70 \%$ & $\begin{array}{l}1 \\
2 \\
3 \\
4 \\
1\end{array}$ & $\begin{array}{l}15,9 \\
16,7 \\
18,9 \\
17,2 \\
18,2\end{array}$ & 17,1 & $\begin{array}{l}16,3 \\
17,0 \\
15,9 \\
18,3 \\
19,1\end{array}$ & 16,8 \\
\hline $90 \%$ & $\begin{array}{l}2 \\
3 \\
4\end{array}$ & $\begin{array}{l}19,3 \\
20,2 \\
22,3\end{array}$ & 20,0 & $\begin{array}{l}21,1 \\
18,2 \\
20,2\end{array}$ & 19,6 \\
\hline $\begin{array}{r}\text { Kontrol (+) } \\
\text { (Ampisilin) }\end{array}$ & 1 & 17,0 & 17,0 & 16,0 & 16,0 \\
\hline $\begin{array}{l}\text { Kontrol ( - ) } \\
\text { (Aquadest) }\end{array}$ & 1 & 6 & 6 & 6 & 6 \\
\hline
\end{tabular}


Tabel 2. Uji Normalitas

\begin{tabular}{llcccrrr}
\hline & \multicolumn{3}{c}{ Kolmogorov-Smirnov $^{\mathbf{a}}$} & \multicolumn{3}{c}{ Shapiro-Wilk } \\
& Konsentrasi & Statistic & df & Sig. & Statistic & df & Sig. \\
\hline Hasil Uji Ekstrak Meniran & Konsentrasi 10\% & .301 & 4 &. & .897 & & 4 \\
Terhadap P.acne & Konsentrasi 30\% & .245 & 4 &. & .916 & 4 & .414 \\
& Konsentrasi 50\% & .272 & 4 &. & .897 & 4 & .418 \\
& Konsentrasi 70\% & .207 & 4 &. & .937 & 4 & .637 \\
& Konsentrasi 90\% & .168 & 4 &. & .984 & 4 & .928 \\
Hasil Uji Ekstrak Meniran & Konsentrasi 10\% & .210 & 4 &. & .982 & 4 & .911 \\
Terhadap Salmonella & Konsentrasi 30\% & .185 & 4 &. & .972 & 4 & .855 \\
& Konsentrasi 50\% & .266 & 4 &. & .903 & 4 & .448 \\
& Konsentrasi 70\% & .242 & 4 &. & .953 & 4 & .735 \\
& Konsentrasi 90\% & .204 & 4 &. & .972 & 4 & .854 \\
\hline
\end{tabular}

Tabel 3. Uji Homogenitas

Levene Statistic

df1

df2

Sig.

Hasil Uji Ekstrak Meniran

Terhadap P.acne

5.689

6

21

.001

Hasil Uji Ekstrak Meniran

3.903

6

21

.009

Terhadap Salmonella

Dari data uji homogenitas (Tabel 3), hasil uji ekstrak daun herba meniran terhadap bakteri $P$.acnes memilliki nilai signifikansi sebesar 0,01 , sedangkan hasil uji ekstrak daun herba meniran terhadap bakteri Salmonella memilliki nilai signifikansi sebesar 0,09. Artinya bahwa data yang diujikan pada bakteri P.acnes tidak terdistribusi secara merata, sedangkan pada data yang diujikan pada bakteri Salmonella terdistribusi secara merata, karena nilai signifikansi $>0,05$.

Tabel 4. Uji Anova

\begin{tabular}{|c|c|c|c|c|c|c|}
\hline & & Sum of Squares & df & Mean Square & $\mathrm{F}$ & Sig. \\
\hline Hasil Uji Ekstrak Meniran & Between Groups & 604.604 & 6 & 100.767 & 106.578 & .000 \\
\hline \multirow[t]{2}{*}{ Terhadap P.acne } & Within Groups & 19.855 & 21 & .945 & & \\
\hline & Total & 624.459 & 27 & & & \\
\hline Hasil Uji Ekstrak Meniran & Between Groups & 712.890 & 6 & 118.815 & 136.925 & .000 \\
\hline \multirow[t]{2}{*}{ Terhadap Salmonella } & Within Groups & 18.222 & 21 & .868 & & \\
\hline & Total & 731.112 & 27 & & & \\
\hline
\end{tabular}


Pada Tabel 4, merupakan hasil uji Anova, menunjukkan bahwa $F$ tabel dari kedua bakteri uji sebesar 2,57. Pada P.acnes didapatkan $F$ hitung sebesar 106,578 dan F hitung Salmonella sp. sebesar 136,925. Dari hasil tersebut, dapat dilihat bahwa $F$ hitung dari kedua bakteri uji > dari $\mathrm{F}$ tabel, maka ekstra daun herba meniran efektif terhadap
Pada Tabel 5 merupakan kesimpulan dari hasil uji Tukey lanjutan setelah data diuji Anova. Dari tabel tersebut, bisa dikatakan bahwa untuk uji ektrak daun herba meniran pada konsentrasi $10 \%$ tidak beda nyata dengan kontrol negatif dan kontrol positif tidak beda nyata dengan konsentrasi $70 \%$. Pada ekstrak yang diujikan terhadap bakteri P.acnes, konsentrasi 10\% tidak

Tabel 5. Rata - Rata Zona Hambat dan Standart Deviasi Pada Tiap Konsentrasi Terhadap Bakteri P.acne dan Salmonella

\begin{tabular}{ccc}
\hline Konsentrasi & $\begin{array}{c}\text { Rata - Rata Zona Hambat } \pm \\
\text { Standart Deviasi } \\
\boldsymbol{P . a c n e}\end{array}$ & $\begin{array}{c}\text { Rata - Rata Zona Hambat } \pm \\
\text { Standart Deviasi } \\
\text { Salmonella }\end{array}$ \\
\hline Konsentrasi $10 \%$ & $7,5 \pm 0,3^{\mathrm{a}}$ & $6,3 \pm 0,2^{\mathrm{a}}$ \\
Konsentrasi $30 \%$ & $11,1 \pm 1,3^{\mathrm{b}}$ & $11,6 \pm 0,6^{\mathrm{b}}$ \\
Konsentrasi $50 \%$ & $13,7 \pm 1,3^{\text {cd }}$ & $14,1 \pm 0,9^{\mathrm{cd}}$ \\
Konsentrasi $70 \%$ & $16,8 \pm 1,0^{\mathrm{d}}$ & $17,1 \pm 1,2^{\mathrm{d}}$ \\
Konsentrasi $90 \%$ & $19,6 \pm 1,2^{\mathrm{e}}$ & $20,0 \pm 1,7^{\mathrm{e}}$ \\
Kontrol positif & $16,0 \pm 0,0^{\mathrm{d}}$ & $17,0 \pm 0,0^{\mathrm{d}}$ \\
Kontrol negatif & $6,0 \pm 0,0^{\mathrm{a}}$ & $6,0 \pm 0,0^{\mathrm{a}}$ \\
\hline
\end{tabular}

pertumbuhan Salmonella dan $P$. acnes.

benda nyata dengan kontrol negatif, sedangkan konsentrasi $50 \%$ dan $70 \%$ tidak beda nyata dengan kontrol positif.

Pada penelitian ini menggunakan uji eksperimental untuk mengetahui efektivitas antibakteri pada ekstrak daun herba meniran dalam menghambat pertumbuhan bakteri Salmonella dan $P$. acnes. Dalam penelitian ini menggunakan metode disk diffusion. Pada metode ini, ekstrak daun herba meniran dapat berdifusi pada media pertumbuhan bakteri melalui kertas cakram yang sudah direndam terlebih dahulu pada tiap konsentrasi pengenceran ekstrak daun herba meniran.

Penggunaan kontrol (+) dan (-) merupakan pembanding dari tiap - tiap perlakukan. Pada kontrol positif menggunakan Antibiotik Gentamicin untuk dibandingkan dengan efektivitas antibakteri daun herba meniran dengan bakteri uji. Pemilihan Gentamicin sebagai kontrol positif karena Gentamicin merupakan antibiotik yang mempunyai daya antibakteri yang baik terhadap bakteri Gram positif maupun Gram negatif. Untuk kontrol (-) menggunakan aquadest, karena aquadest merupakan larutan pengencer pada ekstrak daun meniran, aquades digunakan sebagai kontrol negatif untuk membuktikan bahwa larutan pengencer tidak berpengaruh sebagai antibakteri.

Pada Gambar 1 menunjukkan rata rata zona hambat yang dihasilkan tiap konsentrasi beserta nilai standar deviasi terhadap bakteri Salmonella dan $P$. acnes. Apabila standart deviasi bernilai besar maka data sampel semakin bervariasi. Sebaliknya jika standart deviasinya kecil maka data sampel semakin homogen (hampir sama).

Peningkatan konsentrasi ekstrak daun herba meniran akan diikuti dengan peningkatan kandungan zat bioaktif, sehingga efektivitas antibakterinya juga semakin tinggi. Hal ini ditandai dengan 
bertambahnya diameter zona hambat. Menurut Mangunwardoyo dkk, (2009) mengatakan bahwa daun meniran mengandung beberapa gogolngan senyawa seperti alkaloid, flavonoid, saponin, dan tanin. Keempat golongan senyawa tersebut bersifat sebagai antibakteri, akan tetapi pada penelitian ini tidak dilakukan uji senyawa kandungan daun meniran. Pada Gambar 1 didapatkan data zona hambat pada perlakuan tiap konsentrasi mulai dari $10 \%, 30 \%, 50 \%$, $70 \%$, dan $90 \%$ dengan zona hambat terbesar terdapat pada konsentrasi $90 \%$. Beberapa kandungan zat bioaktif dari ekstrak daun herba meniran yang berfungsi sebagai antibakteri adalah flavonoid, alkaloid, dan saponin. Flavonoid merupakan kandungan senyawa yang dapat mengganggu komponen penyusun peptidoglikan pada sel bakteri sehingga lapisan dinding sel tidak terbentuk secara utuh yang menyebabkan kematian sel (Radji, 2014). Mekanisme alkaloid pada ekstrak meniran juga berfungsi sebagai antibakteri dengan menghambat sintesis asam nukleat dan menghambat metabolisme energi sedangkan mekanisme kerja senyawa saponin sebagai antibakteri dengan cara menyebabkan kebocoran protein dan enzim dalam sel (Kristanti dkk, 2008; Radji, 2014). Penelitian ini sejalan dengan penelitian yang dilakukan oleh Mangunwardoyo dkk (2009) yaitu mengujikan ekstrak meniran terhadap bakteri S.aureus (Gram +); E.coli dan P.aeruginosa (Gram -) serta khamir C.albicans yang menunjukkan aktivitas penghambatan terhadap bakteri S.aureus dan khamir C.albicans, akan tetapi penelitian ini tidak menuliskan besarnya zona jernih yang terbentuk.

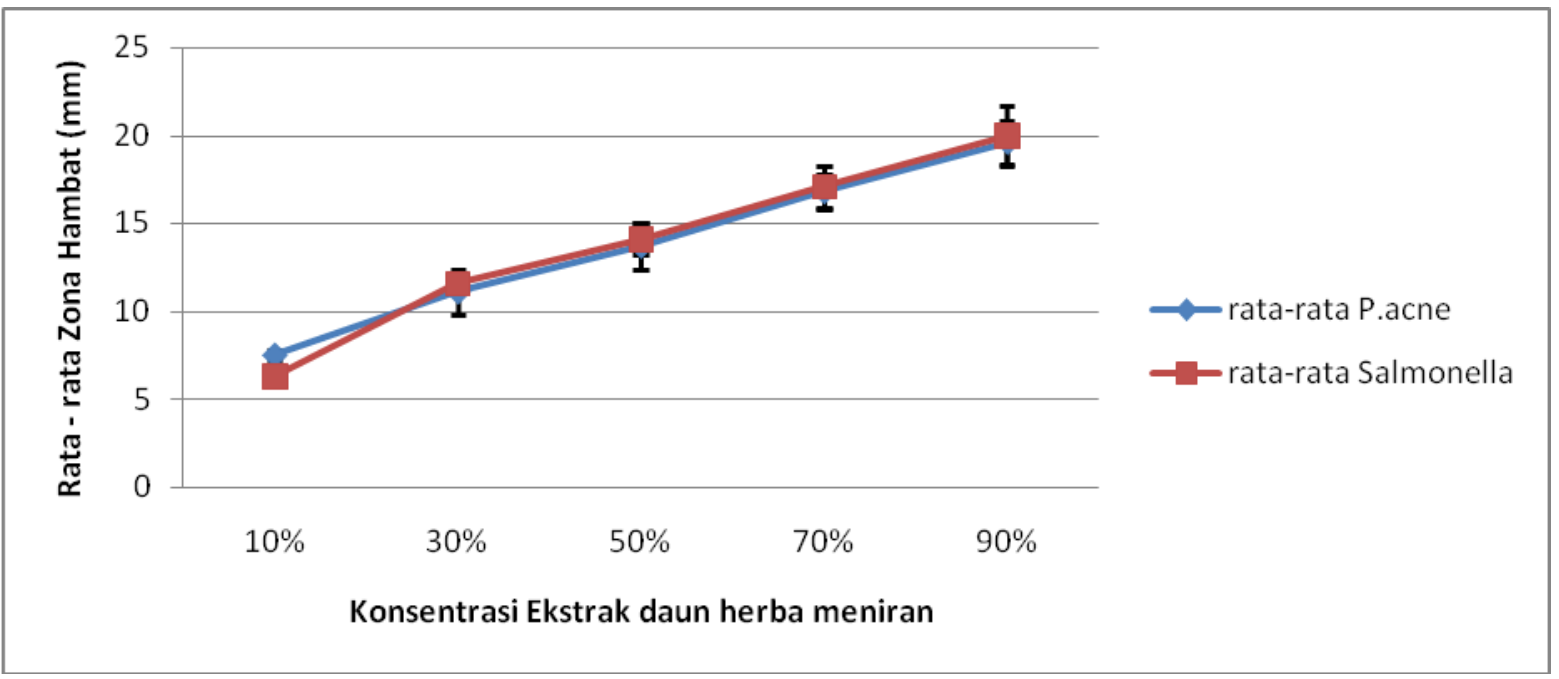

Gambar 1. Rata - Rata Zona Hambat dan Standart Deviasi Pada Tiap Konsentrasi Terhadap Bakteri P.acne dan Salmonella

Adanya perbedaan zona hambat yang terjadi pada bakteri Salmonella dan $P$. acnes disebabkan juga karena adanya perbedaan struktur dinding sel kedua bakteri yang mempengaruhi kerja ekstrak daun meniran sebagai senyawa antibakteri, artinya ekstrak daun herba meniran akan menimbulkan efek jika ekstrak tersebut dapat masuk ke dalam sel bakteri. Bakteri $P$. acnes merupakan bakteri gram positif yang memiliki 3 lapisan yaitu selaput sitoplasma, lapisan peptidoglikan yang tebal dan simpai. Bakteri Salmonella merupakan bakteri 
gram negatif yang memiliki beberapa lapisan yaitu selaput sitoplasma, lapisan peptidoglikan yang tipis, dan lapisan luar yang terdiri dari lipoprotein dan lipopolisakarida. Perbedaan ketebalan lapisan peptidoglikan pada kedua bakteri tersebut membuat $P$. acnes memiliki zona hambat yang lebih rendah dari pada Salmonella (Jawetz dkk, 2013).

Menurut Uswatun mengatakan bahwa ada beberapa faktor yang harus diperhatikan pada saat melakukan uji sensitivitas antibakteri, yaitu suhu dan waktu inkubasi untuk memperoleh perkembangbiakan bakteri yang optimal yaitu $37^{\circ} \mathrm{C}$ dan 24 jam; pada kultur biakan bakteri yang ditandai dengan adanya perubahan media pemupuk menjadi keruh, apabila suspensi kultur bakteri terlalu keruh, maka diameter zona hambat semakin kecil artinya yang semula hasilnya sensitif dapat berubah menjadi resisten begitu juga sebaliknya; setelah penanaman bakteri pada media MHA, waktu pengeringan/peresapan suspensi mikroba ke dalam media agar dibiarkan mengering selama 5 menit, apabila lebih dari batas waktu yang ditentukan dapat mempersempit diameter zona hambat, sehingga yang semula hasilnya sensitif berubah menjadi resisten; perhitungan dalam pembuatan komposisi media untuk perkembangbiakan mikroba harus benar, karena pertumbuhan mikroba membutuhkan suatu substrat makanan yang mengandung nutrien yaitu berupa garam-garam anorganik dan senyawasenyawa organik; ketebalan media yang digunakan sekitar 4-6 mm apabila kurang dari batas tersebut difusi obat akan lebih cepat, dan apabila lebih dari batas itu maka difusi obat akan lebih lambat, media yang terlalu tebal atau terlalu tipis menyebabkan penanaman mikroba dan peresapan ekstrak kurang optimal; memperhatikan antibiotik pembanding yang akan digunakan agar diperhatikan cara penyimpanan dan tanggal kadaluarsanya.

\section{SIMPULAN DAN SARAN}

\section{SIMPULAN}

Simpulan dari penelitian ini ialah ekstrak daun herba meniran memiliki efektifitas sebagai antibakteri dalam mengahambat pertumbuhan bakteri Salmonella dan $P$. acnes, dengan zona hambat yang dihasilkan terhadap Salmonella sebesar $20 \mathrm{~mm}$ dan terhadap $P$. acnes sebesar 19,6 mm.

\section{SARAN}

Daun herba Meniran memiliki manfaat dan kegunaan bagi kehidupan manusia. Agar pembaca dapat mengetahui berbagai manfaatnya, sehingga adapun beberapa saran penelitian yang dilakukan untuk kedepannya yaitu perlu dilakukan penelitian lanjutan dengan menggunakan metode dilusi, dan penggunaan bakteri uji selain Salmonella dan P. acnes; perlu dilakukan penelitian lanjutan dengan identifikasi kandungan senyawa metabolit pada ekstrak daun herba meniran yang akan di uji antibakterinya.

\section{DAFTAR PUSTAKA}

Bukar, A. 2010. Antimicrobal Profile of Moringa oleifera Lam. Ektract Againts Some Food Microorganisms. Bayero Journal Pure and Applie Science, 3 (1); 4348.

Djauhari, E dan Hermani. 2004. Gulma Berkhasiat Obat. Jakarta: Penebar Swadaya.

Hadiki, H. 2014. Audit Kualitatif Pemberian Antibiotik untuk Pasien Gangren Diabetik Disertai Insufisiensi 
Adrenal Sekunder: Laporan Kasus, 41(1); 43-44.

Hariyani, Tiwuk D., Suranto \& Edi P. 2013. Studi Variasi Anatomi dan Kandungan Flavonoid Lima Spesies Anggota Genus Phyllantus. Jurnal Pasca UNS ElVivo 1(1): Hal: 1 - 14.

Jawetz, Melnick, \& Adelberg's. 2013. Mikrobiologi Kedokteran. Jakarta: Salemba Medika.

Kardinan, Agus dan Fauzi Rahman K. 2004. Sehat dengan Ramuan Tradisional Meniran Penambah Daya Tahan Tubuh Alami. Jakarta: Agro Media Pustaka.

Kemenkes RI. 2010. Peraturan Menteri Kesehatan Republik Indonesia Nomor 003 / MENKES / PER /I / 2010. Tentang Saintifikasi Jamu dalam Penelitian Berbasis Pelayanan

Kesehatan.http://www.depkes.go. id/article/print/1102/obattradisional-masuk-dalam-sistem-pelayanan-kesehatan-formal.html Diakses pada tanggal 29 Juli 2017.

Kristanti A, N., Nanik S, A., Mulyadi T., Bambang K. 2008. Fitokimia. Surabaya: Airlangga University Press.

Mahmoud, Barakat, S. M. 2012. Salmonella - a Dangerous Foodborne Pathogen. Croatia: InTech.

Mangunwardoyo, W., Eni C., Tepy U. 2009. Ekstraksi dan Identifikasi Senyawa Antimikroba Herba Meniran (Phyllanthus niruni L.) Jurnal IImu Kefarmasian Indonesia Vol. 7 (2009).
Muharram dan Nur J. 2009. Isolasi dan Identifikasi Sterol dari Ekstrak nHeksan Daun Meniran Hijau Phyllanthus niruni L. (Euphorbiaceae). Jurnal Bionature 10(2): Hal $50-55$.

Paithankar V. V., Raut K. S., Charde R. M., and Vyas J. V. 2011. Phyllanthus niruni: A magic Herb. Research in Pharmacy 1(4): 1 9.

Pratiwi, Sylvia, T. 2008. Mikrobiologi Farmasi. Jakarta: Penerbit Erlangga.

Pui, C. F., Wong, W. C., Chai L. C., Tunung, R., Jeyaletchumi, P., Noor H, M, S., Ubong, A., Farinazleen, M. G., Cheah, Y, K., Son R. 2011. Review Article Salmonella: a foodborne pathogen. International Food Research Journal 18: 465 - 473.

Rahman, Dwiariawan, T., E. M. Sutrisna., Anika C. 2012. Uji Efek Antibakteri Ekstrak Etil Asetat dan Kloroform Meniran (Phyllantus niruni Linn) Terhadap Pertumbuhan Bakteri Stapylococcus aureus ATCC 6538 dan Escherichia coli ATCC 11229 Secara In vitro. Jurnal Biomedika 4(2): Hal $18-25$.

Radji, Maksum. 2014. Mekanisme Aksi Molekuler Antibiotik dan Kemoterapi. Jakarta: EGC.

Repi, Novianto, B., Christi M., Jane W. 2016. Uji Efek Antibakteri Ekstrak Kulit Kayu Manis (Cinnamomum burmannii) Terhadap Escherichia coli dan Streptococcus pyogenes. Jurnal e-Biomedik (eBm) 4(1): Hal $1-5$. 
Rivai, Harrizul., Refilia, S., Agusri, B. 2013. Karakterisasi Ekstrak Herba Meniran (Phyllantus niruni Linn) Dengan Analisa Flouresensi. Jurnal Farmasi Higea 5 (2): Hal $15-23$.

Fatisa, Y. 2013. Daya antibakteri ekstraks kulit dan biji buah pulasan (Nephelium mutabile) terhadap Stapylococcus aureus dan Escherichia coli secara invintro. Jurnal pertenakan. 1(10), 31-38. 